\section{Industrial heritage celebrated in art}

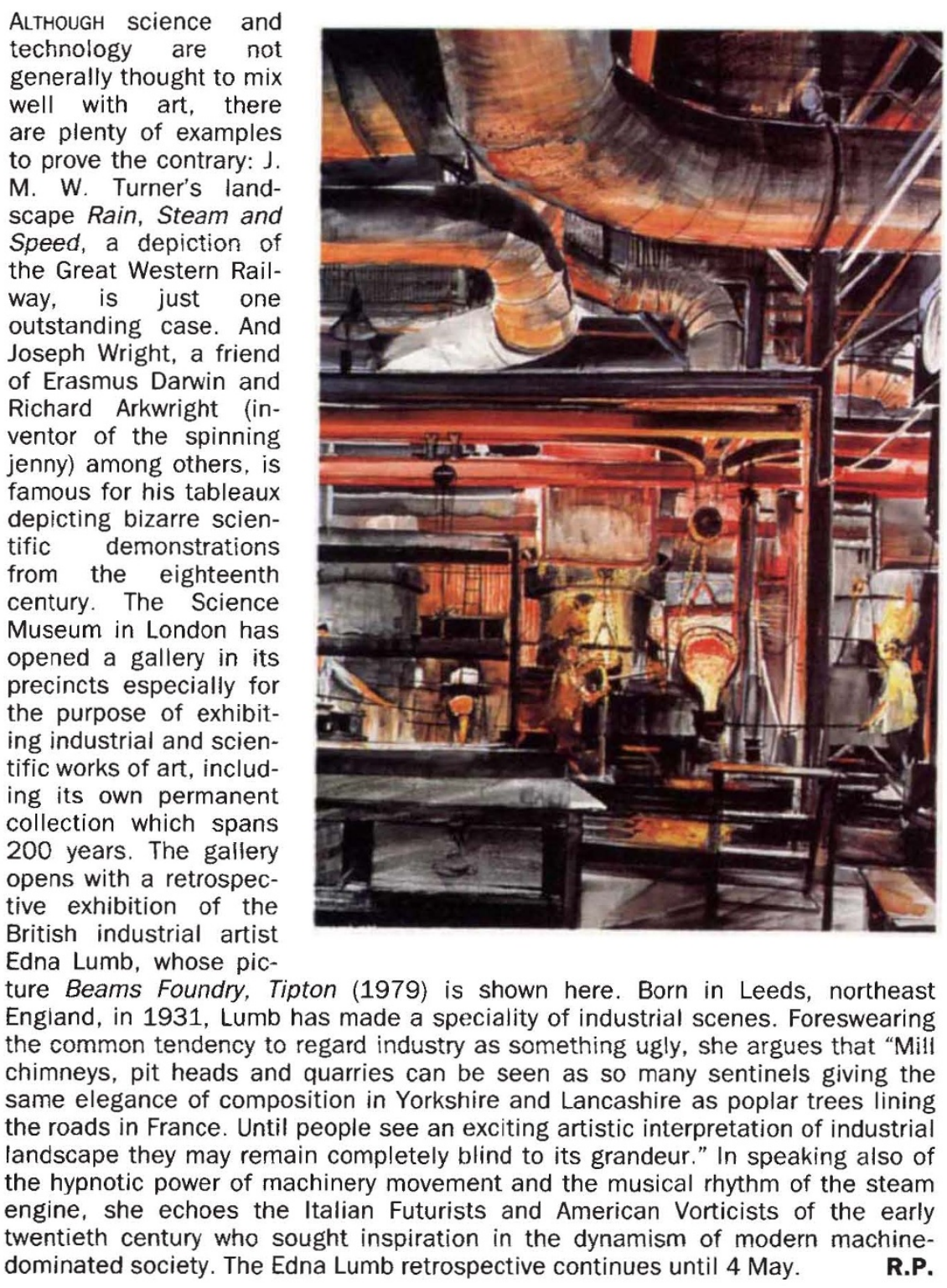

analogous to the reversion of the rastransformed phenotype in fibroblasts by overexpression of Rap1a (ref. 9). Little is known about the normal functions of either Rap1 or Ras2 (a homologue of mammalian R-ras) in any system, so further genetic analysis of their effects on eye development could well prove productive.

The simplest model to include all the genes so far characterized on the R7 determination pathway is shown in the figure. Boss, expressed on the surface of R8 cells, activates Sev on adjacent R7 precursor cells. Subsequent activation of Sos catalyses the conversion of Ras1GDP to Ras1-GTP, which then initiates the downstream signals necessary to induce R7-specific differentiation. Establishing a link between Sev and Sos will require biochemical investigation, but one possibility is that Sev could stimulate Sos activity directly by tyrosine phosphorylation. In addition, if Sos is proved to be an exchange factor for Ras1, then its isolation as an $E(s e v)$ locus would imply that nucleotide exchange on Ras1 is a rate-limiting step in this signalling process. This is in contrast to a model for Ras activation in T cells, where the level of Ras-GTP is believed to be controlled by receptor-mediated inhibition of a GTPase-activating protein (GAP) (see figure) ${ }^{10}$. It is quite possible that either or both of these mechanisms can be used to regulate Ras-GTP levels under different circumstances.

Although the model in the figure is consistent with the data, studies on receptor tyrosine kinases in mammalian cells suggest that the Sev signalling pathway is probably not so straightforward.
First, some tyrosine kinases have been shown to act on several targets, including phospholipase $\mathrm{C} \gamma$, phosphatidylinositol 3-kinase, Raf and RasGAP (ref. 11). It would therefore be surprising if Ras1 were the sole mediator of Sev signalling; although expression of Ras $1^{\text {Vall2 }}$ can bypass the requirement for Sev, it may do so indirectly by leading to the production of signals not normally activated through endogenous Ras1. Second, stimulation of two different transmembrane receptors is often required for an optimal cellular response, for example in mitogenesis, and a model where Ras and Sev act on parallel pathways cannot be ruled out. The sensitivity of Sev-mediated signalling to changes in Sos levels could still be explained if Sos and Ras were regulatory components of a pathway acting synergistically with Sev.

\section{Downstream targets}

These complexities aside, the importance of the work of Rubin and colleagues is that they have identified Ras by genetic means as a crucial component of a receptor-mediated signal transduction pathway in development, and that this system is amenable to further genetic analysis. The next step is to define other components of the pathway downstream of Ras. The method of isolating the $E(s e v)$ mutations is unlikely to pick up downstream targets that are normally expressed in excess, and for which a twofold reduction in activity would not be rate-limiting. But there are already five other $E(\operatorname{sev})$ loci to investigate, which could include an effector molecule directly regulated by Ras. It will be particularly interesting to see whether any of these genes share homology with the two characterized GTPase-activating proteins for mammalian Ras, RasGAP and NF1, as this could resolve the continuing controversy of whether these proteins are downregulators or the true effectors of Ras function.

Anne J. Ridley and Alan Hall are in the Chester Beatty Laboratories, Institute of Cancer Research. Fulham Road, London SW3 6JB, UK.

. Fortini, M. E., Simon, M. A. \& Rubin, G. M. Nature 355 559-561 (1992).

2. Simon, M. A., Bowtell, D. D. L., Dodson, G. S Laverty, T. R. \& Rubin, G. M. Cell 67, 701-716 (1991)

3. Rubin, G. M. Cell 57, 519-520 (1989)

4. Krämer, H. Call $57,519-520(1989)$. Nature 352 207-212 (1991).

5. Rogge, R. D., Karlovich, C. A. \& Banerjee, U. Cell 64 39-48 (1991)

6. Beitel, G. J., Clark, S. G. \& Horvitz, H. R. Nature 348 503-509 (1990)

7. Han, M. \& Sternberg, P. W. Cell 63, 921--931 (1990).

8. Mariharan, I. K., Carthew, R. W. \& Rubin, G. M. Cell 67. 717-722 (1991)

9. Kitayama, H., Sugimoto, Y., Matsuzaki, T., Ikawa, Y. \& Noda, M. Cell 56, 77-84 (1989)

10. Downward, J., Graves, J. D. Warne, P. H., Rayter, S. \& Cantrell, D. A. Nature 346, 719-723 (1990).

11. Cantley, L. C. et al. Cell 64, 281-302 (1991). 